\title{
PERENCANAAN STRATEGI SISTEM DAN TEKNOLOGI INFORMASI MENGGUNAKAN FRAMEWORK TOGAF VERSI 9.1 DI SMK KESEHATAN HIDAYAH MEDIKA TASIKMALAYA
}

\author{
Givany Salsabila Siti Rukoyah ${ }^{1}$, Rahmi Nur Shofa ${ }^{2}$, Rianto ${ }^{3}$ \\ 1,2,3 Program Studi Teknik Informatika, Fakultas Teknik, Universitas Siliwangi
}

\section{Article Info:}

Dikirim: 15 Maret 2019

Direvisi: 17 Mei 2019

Diterima: 19 Mei 2019

Tersedia Online: 29 Juni 2019

Penulis Korespondensi:

Rianto

Program Studi Teknik Informatika, Fakultas Teknik,

Universitas Siliwangi,

Tasikmalaya, Indonesia

Email: rianto@unsil.ac.id

\begin{abstract}
Abstrak: SMK Kesehatan Hidayah Medika Tasikmalaya merupakan sekolah yang memulai ijin operasional untuk melaksanakan PPDB (Penerimaan Peserta Didik Baru) pada tahun 2016. Pemanfaatan terhadap SI/TI saat ini belum sepenuhnya mengikuti perkembangan serta belum memiliki perencanaan strategi SI/TI jangka panjang menggunakan framework tertentu. Hal ini berdampak kepada tidak selarasnya antara strategi SI/TI dengan tujuan bisnis organisasi. Perencanaan arsitektur enterprise merupakan salah satu cara yang digunakan untuk mewujudkan tercapainya kepentingan organisasi secara keseluruhan. TOGAF ADM dijadikan sebagai pedoman untuk merencanakan arsitektur SI/TI jangka panjang. Tahapan TOGAF ADM yang dilakukan berfokus pada perencanaan arsitekturnya saja, yaitu Preliminary Phase, Architecture Vision (Phase A), Business Architecture (Phase B), Information System (Phase C), Technology Architecture (Phase D), dan Opportunities and Solutions (Phase E). Hasil dari perencanaan strategi SI/TI adalah blueprint dengan 18 pemodelan Business Process Model and Notation (BPMN) untuk arsitektur bisnis, 11 pemodelan Use Case Diagram untuk arsitektur aplikasi, 11 pemodelan Class Diagram untuk arsitektur data, arsitektur teknologi yang menghasilkan infrastruktur jaringan usulan dimodelkan dengan Communication Enginering Diagram, platform technology dimodelkan dengan Platform Decomposition Diagram, katalog teknologi dimodelkan dengan Technology Portfolio Catalog; analisis kesenjangan (gap) arsitektur SI/TI dimodelkan dengan Matrix Analysis Gap, portofolio aplikasi menggunakan analisis McFarlan Strategic Grid, serta roadmap implementasi arsitektur SI/TI.
\end{abstract}

Kata kunci: arsitektur enterpris; McFarlan strategic grid; TOGAF ADM.

Abstract: Hidayah Medika Health Vocational School Tasikmalaya is a school which begin operational permission for starting PPDB (New Student Admission) in 2016. Now, the utilization of Information System and Technology is not fully following development and don't have long term Information System and Technology strategy planning with specific framework yet. This will have an impact to not aligned between Information System and Technology strategy with business organization purpose. Enterprise architecture planning is how to reach the overall organization benefit. TOGAF ADM is made as rule for long term Information System and Technology strategy planning. The stages of TOGAF ADM only focusing in the architecture planning is Preliminary Phase,: Architecture Vision (Phase A), Business Architecture (Phase B), Information System (Phase C), Technology Architecture (Phase D), and Opprtunities and Solutions (Phase E). The result from Information System and Technology strategy planning is a blueprint which consist of 18 Business Process Model and Notation (BPMN) modelling for business architecture, 11 Use Case Diagram modelling for application architecture, 11 Class Diagram modelling for data architecture, technology architecture which produce proposed network infrastructure modelled with Communication Enginering Diagram, platform technology modelled with Platform Decomposition Diagram, technology catalog modelled with Technology Portfolio Catalog; analysis gap of Information System and Technology architecture modelled with Matrix Analysis Gap, application portfolio using McFarlan Strategic Grid analysis, and roadmap implementation Information System and Technology architeture.

Keywords: enterprise architecture; McFarlan strategic grid; TOGAF ADM. 


\section{PENDAHULUAN}

Pemanfaatan SI/TI dalam organisasi memiliki faktor pendorong yang ditandai dengan semakin meningkatnya kebutuhan dalam fungsi bisnis yang dijalankan. Hal tersebut menjadi sebuah masalah untuk bagaimana menyelaraskan antara strategi SI/TI dengan tujuan bisnis organisasi. Organisasi harus melaksanakan perencanaan strategi terhadap SI/TI yang akan menyediakan perencanaan jangka panjang yang tepat guna. Tiga alasan yang menunjukkan pentingnya perencanaan strategi yaitu dapat memberikan kerangka dasar, pemahaman terhadap perencanaan strategi akan mempermudah pemahaman bentuk-bentuk perencanaan lainnya, merupakan titik permulaan bagi pemahaman dan penilaian kegiatan-kegiatan manajer serta organisasi [1].

Enterprise architecture (EA) merupakan salah satu cara mewujudkan gambaran tentang organisasi secara utuh, logis, dan lengkap yang hasilnya meliputi arsitektur bisnis dari organisasi, arsitektur data yang akan digunakan, arsitektur aplikasi yang akan dibangun, dan arsitektur teknologi yang nantinya mendukung jalannya aplikasi [2]. Tujuannya adalah untuk mengoptimalkan seluruh organisasi, dari proses yang ter-fragmentasi (baik manual maupun otomatis) kedalam lingkungan terintegrasi yang responsif terhadap perubahan dan mendukung penyampaian strategi bisnis organisasi [3].

Organisasi yang masih belum terdapat arsitektur enterprise dan keperluan untuk pengembangan arsitektur enterprise yang mudah serta jelas, maka dalam pembuatan arsitektur enterprise yang tepat adalah menggunakan TOGAF (The Open Group Architecture Framework) karena memiliki metode dan tools yang detail untuk mengimplementasikannya [4]. TOGAF memiliki metode yaitu ADM (Architecture Development Method) yang digunakan sebagai panduan atau alat untuk merencanakan, merancang, mengembangkan dan mengimplementasikan arsitektur sistem informasi untuk organisasi [5]. TOGAF ADM merupakan sebuah metode yang kompleks yang mampu memenuhi seluruh kebutuhan pengembangan EA yaitu sebesar 92\% [6].

Penelitian yang telah dilakukan sebagai dasar mengenai penelitian ini diantaranya [1] menguraikan tentang implementasi perencanaan strategi pada organisasi sosial bidang pendidikan, khususnya pada sebuah sekolah. Hasil penelitiannya membuktikan bahwa perencanaan strategi yang disusun pada sebuah sekolah dan diimplementasikan dengan baik mampu memberikan manfaat yang besar bagi sekolah tersebut dalam mencapai tujuannya. Proses penyusunan perencanaan strategis yang tertata rapi pada sebuah sekolah membuat sekolah tersebut berhasil mencapai tujuannya.

Penelitian [7] melakukan analisis arsitektur terhadap teknologi informasi di SMK Negeri Majalengka. Teknologi informasi yang digunakan belum saling terintegrasi dan kurang efisien. Maka dibuatlah perancangan arsitektur yang dapat mewujudkan keselarasan antara proses bisnis organisasi dan sistem informasi. Metode perencanaan arsitektur yang digunakan adalah TOGAF ADM dengan tahapan Preliminary phase hingga Opportunities and solution. Tools pemodelan yang digunakan adalah Value Chain Diagram, Business Process Working Sheet, Business Process Model and Notation (BPMN), Class Diagram, Use Case Diagram, Software Platform Architecture, dan Network Computing Diagram. Hasil dari penelitian ini adalah blueprint arsitektur bisnis, arsitektur data, arsitektur aplikasi, arsitektur teknologi, dan usulan perbaikan teknologi yang dapat mengintegrasikan seluruh unit sistem serta mendukung aktifitas bisnis di SMKN 1 Majalengka.

Penelitian [8] melakukan implementasi sistem e-Cors yang kurang efektif, disebabkan karena kurang matangnya perencanaan sistem oleh pihak Bimbel SG. Sistem yang dikembangkan pun masih berupa adhoc dan tidak dilakukan oleh tenaga khusus. Maka dibuatlah sebuah perencanaan arsitektur enterprise menggunakan framework TOGAF ADM dengan tahapan dimulai dari fase Preliminary hingga fase Migration Planning. Pemodelan digambarkan menggunakan tools Principle Catalog, 5W+1H, Value Chain, Flowchart, McFarlan's Strategic Grid, dan Archimate. Blueprint merupakan hasil dari penelitian ini berupa arsitektur bisnis, data, aplikasi, teknologi, analisis gap, dan roadmap implementasi aplikasi berdasarkan analisis McFarlan's Strategic Grid.

Penelitian [9] merancang arsitektur enterprise sistem informasi Sekolah untuk menunjang SMK Informatika Sumedang dalam mewujudkan visinya, menggunakan TOGAF ADM versi 9.1. Tahapan yang dilakukan adalah Preliminary Phase hingga Migration Planning (fase F). Tools pemodelan yang digunakan adalah Value Chain Diagram, Stakeholder Map Matrix, Perspektif finansial, Class Diagram, Roadmap, dan McFarlan Strategic Grid. Hasil dari penelitian ini adalah blueprint arsitektur untuk menyelesaikan permasalahan sistem informasi yang masih belum terintegrasi dan penunjang proses pada sekolah secara menyeluruh.

Penelitian [5] merancang model arsitektur sistem informasi di Universitas Suryakencana, yang belum memiliki pedoman dalam pemanfaatan sistem dan teknologi informasi. Pengelolaannya hanya bersandarkan pada kebutuhan sesaat tanpa adanya sebuah rancangan yang komprehensip. Maka dibuatlah sebuah perancangan pemodelan TOGAF ADM dengan tahapan Preliminary Framework and Principle hingga Migration Planning. Tools pemodelan yang digunakan adalah Value Chain Diagram, Business Process Modelling and Notation (BPMN), Class Diagram, Application Portfolio, Platform Aplikasi, Infrastructure Topology, Analis Gap, dan Roadmap. Hasil dari penelitian ini adalah perancangan arsitektur yang selaras dengan visi Universitas, pemodelan bisnis, pemodelan arsitektur sistem informasi yang terdiri dari 35 entitas data dari 7 fungsi bisnis dan 36 aplikasi, pemodelan arsitektur teknologi yang diuraikan dalam bentuk aliran informasi, platform aplikasi dan infrastruktur teknologi, gap analisis yang terdapat 5 sistem informasi yang baru dan 3 sistem yang diperbaharui, 
dan perencanaan migrasi yang terdefinisi 8 aplikasi termasuk front office system dan 28 aplikasi termasuk back office system dengan urutan impelementasinya.

Hasil dari kajian literatur yang telah dilakukan, jika dibandingkan dengan penelitian kali ini, perencanaan strategi yang menjadi domain penelitian adalah pada SMK Kesehatan Hidayah Medika Tasikmalaya yang memulai ijin operasional pada bulan juni 2016 dan melaksanakan PPDB (Penerimaan Peserta Didik Baru) pada juli 2016. Hal ini menyebabkan pemanfaatan SI/TI sepenuhnya belum mengikuti perkembangan serta pelaksanaannya belum memiliki perencanaan arsitektur di bidang SI/TI menggunakan framework tertentu untuk jangka panjang. Oleh karena itu, SMK Kesehatan Hidayah Medika Tasikmalaya perlu membuat sebuah perencanaan strategi di bidang SI/TI untuk mencapai tujuan bisnis organisasi.

Perencanaan strategi di bidang SI/TI dimodelkan menggunakan TOGAF ADM dengan fase yang berbeda pada setiap tahapan ADM yang disesuaikan dengan kebutuhan domain penelitian. Tools atau produk kerjanya pun mengacu pada kajian literatur dan pemodelan pokok pada TOGAF. Tujuan dari penelitian ini adalah menghasilkan blueprint dari perencanaan strategi yang disusun menggunakan TOGAF versi 9.1 yang dapat mendukung proses bisnis di SMK Kesehatan Hidayah Medika Tasikmalaya. Dan menganalisa kesenjangan ( $g a p$ ) dari arsitektur bisnis, arsitektur data, arsitektur aplikasi, serta arsitektur teknologi yang akan dipetakan kedalam roadmap implementasi arsitektur SI/TI.

\section{METODOLOGI PENELITIAN}

Tahapan dalam penelitian ini dimulai dari studi pustaka, pengumpulan data yaitu observasi, wawancara, dan kuesioner, melakukan pemodelan arsitektur enterprise dengan menggunakan framework TOGAF (The Open Group Architecture Framework) versi 9.1 dan ADM (Architecture Development Method) sebagai metode untuk menghasilkan blueprint arsitektur enterprise, melakukan analisa kesenjangan (gap), membuat roadmap implementasi perencanaan arsitektur SI/TI berdasarkan analisis pemetaan portofolio aplikasi, serta penarikan kesimpulan.

\subsection{Studi Pustaka}

Studi pustaka bertujuan untuk mengumpulkan informasi-informasi yang relevan dangan topik yang sedang diteliti yaitu dengan mempelajari penelitian-penelitian sebelumnya dari buku, jurnal, dan artikel yang berhubungan dengan topik penelitian tentang perencanaan strategi, arsitektur enterprise, sistem informasi dan teknologi informasi, perencanaan strategi sistem teknologi informasi menggunakan Framework TOGAF, metode TOGAF ADM, serta tools yang digunakan dalam pemodelan arsitektur enterprise.

\subsection{Pengumpulan Data}

Pengumpulan data yang dilakukan yaitu observasi, wawancara, dan kuesioner yang ditujukan kepada para pegawai di SMK Kesehatan Hidayah Medika Tasikmalaya.

\subsubsection{Observasi}

Observasi dilakukan dengan cara mengamati secara langsung tempat penelitian yaitu SMK Kesehatan Hidayah Medika Tasikmalaya. Observasi dilakukan untuk mendapatkan informasi, seperti sejarah singkat, visi dan misi, struktur organisasi, sumber daya manusia, tupoksi, aktivitas, alur setiap aktivitas dan sistem yang sedang berjalan pada setiap bagian enterprise. Observasi dilakukan juga untuk mengamati penggunaan sistem dan teknologi informasi saat ini, yang berfungsi sebagai penggerak aktivitas pada tempat penelitian.

\subsubsection{Wawancara}

Wawancara dilakukan dengan cara melakukan interaksi secara langsung dengan pihak yang memiliki peran penting atau yang dianggap mengetahui semua hal dilihat pada struktur organisasi yaitu Kepala Sekolah, Kepala Tata Usaha, Wakasek dan Kepala Program Jurusan di SMK Kesehatan Hidayah Medika Tasikmalaya. Pertanyaan diajukan kepada salah seorang yang mengetahui tentang sistem dan teknologi informasi untuk mendapatkan informasi yang berhubungan dengan kondisi sistem dan teknologi informasi yang sedang berjalan, serta kepada tiap bagian untuk mendapatkan informasi tentang kondisi tiap bagian yang sedang berjalan.

\subsubsection{Kuesioner}

Kuesioner dilakukan dengan memberikan pertanyaan-pertanyaan kepada responden pemangku kebijakan sesuai dengan analisis keterhubungan stakeholder, yang berkaitan dengan penilaian aplikasi saat ini dan aplikasi usulan pada organisasi. Tujuan kuesioner ini adalah untuk memetakan aplikasi yang digunakan saat ini dan aplikasi usulan menggunakan analisis McFarlan Strategic Grid. Kuesioner yang dihasilkan akan menjadi sebuah 
portofolio aplikasi yang dapat mempermudah mengambil keputusan dalam melakukan urutan atau roadmap implementasi aplikasi pada organisasi.

\subsection{Perencanaan Arsitektur Enterprise}

Perencanaan arsitektur enterprise yang dilakukan adalah menggunakan framework TOGAF versi 9.1 dengan metode ADM. TOGAF ADM versi 9.1 ini merupakan metode yang menjelaskan secara rinci bagaimana cara merancang, membangun, mengelola, dan mengimplementasikan arsitektur enterprise [10]. Tahapan ADM dan tools pemodelan arsitektur yang digunakan adalah Preliminary Phase dengan prinsip 5W $+1 \mathrm{H}$ dan Principles Catalog; Architecture Vision (Phase A) dengan tools Value Chain Diagram dan Stakeholder Map Matrix; Business Architecture (Phase B) dengan tools Actor/Role Matrix dan BPMN (Business Process Model and Notation); Information System Architecture (Phase C) dengan tools Application Portfolio Catalog, Use Case Diagram, dan Class Diagram; Technology Architecture (Phase D) dengan tools Communication Engineering Diagram, Platform Decomposition Diagram, dan Technology Portfolio Catalog; Opportunities and Solutions (Phase E) dengan tools Matrix Analysis Gap, McFarlan Strategic Grid dan Roadmap [3].

\subsection{Hasil dan Pembahasan}

Pembahasan berisi tentang metodologi perencanaan arsitektur enterprise di SMK Kesehatan Hidayah Medika Tasikmalaya menggunakan TOGAF ADM mulai dari melakukan persiapan sampai dengan menyusun roadmap implementasi aplikasi dan teknologi dari perencanaan arsitektur yang dibuat. Hasil yang diperoleh adalah blueprint yang dapat mendukung proses bisnis di SMK Kesehatan Hidayah Medika Tasikmalaya.

\subsection{Kesimpulan}

Kesimpulan merupakan bagian akhir dari metodologi penelitian yang memberikan sebuah intisari yang telah dilakukan dari mulai studi pustaka, pengumpulan data, perencanaan arsitektur enterprise, dan sebuah hasil atau temuan yang diperoleh terhadap penelitian.

\section{HASIL DAN PEMBAHASAN}

\subsection{Preliminary Phase}

Fase preliminary ini bertujuan untuk menentukan ruang lingkup yang terlibat selama melakukan perencanaan arsitektur dengan mengidentifikasi $5 \mathrm{~W}+1 \mathrm{H}$ (what, who, where, when, why dan how) serta menentukan prinsip-prinsip acuan dasar perencanaan arsitektur enterprise pada SMK Kesehatan Hidayah Medika Tasikmalaya menggunakan Principle Catalog [3]. Berikut ini Tabel 1. menjelaskan identifikasi $5 \mathrm{~W}+1 \mathrm{H}$ dan Tabel 2. menjelaskan principle catalog.

\section{Tabel 1. Identifikasi objek 5W+1H}

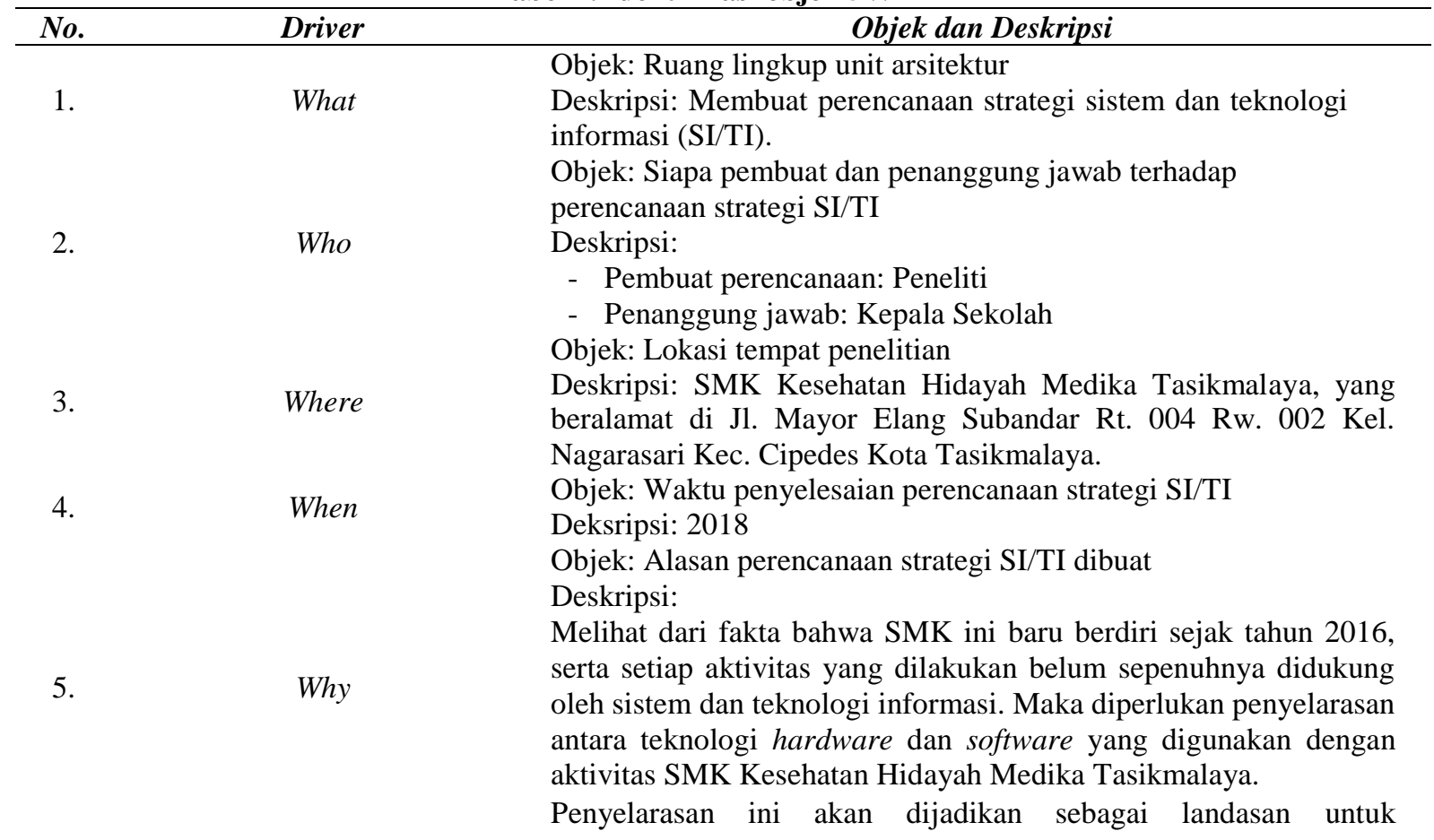




\begin{tabular}{|c|c|c|}
\hline No. & Driver & Objek dan Deskripsi \\
\hline & & $\begin{array}{l}\text { pengembangan implementasi SI/TI dengan membuat katalog dan } \\
\text { diagram arsitektur yang mengintegrasikan modul-modul yang } \\
\text { dibutuhkansehinggadapat menghasilkan blueprint dan roadmap } \\
\text { aplikasi. }\end{array}$ \\
\hline \multirow{4}{*}{6.} & \multirow{4}{*}{ How } & $\begin{array}{l}\text { Objek: Penentuan pembuatan perencanaan strategi SI/TI } \\
\text { Deksripsi: }\end{array}$ \\
\hline & & Perencanaan strategi SI/TI dirancang menggunakan metodologi \\
\hline & & TOGAF ADM versi 9.1. dengan tahapan Preliminary Phase, \\
\hline & & $\begin{array}{l}\text { Architecture, Technology Architectur, dan Opportunities and } \\
\text { solutions. }\end{array}$ \\
\hline
\end{tabular}

Tabel 2. Prinsip-prinsip acuan dasar (tabel principle catalog)

\begin{tabular}{|c|c|c|}
\hline No. & Prinsip & Tujuan \\
\hline 1. & $\begin{array}{l}\text { Arsitektur yang dibuat harus disesuaikan } \\
\text { dengan tujuan dan proses bisnis atau } \\
\text { aktivitas di SMK Kesehatan Hidayah } \\
\text { Medika Tasikmalaya }\end{array}$ & 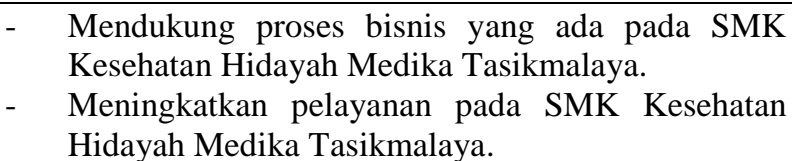 \\
\hline 2. & Manajemen data & $\begin{array}{l}\text { - Membatasi hak akses data berdasarkan kebutuhan } \\
\text { dari masing-masing pengguna. } \\
\text { - Memelihara data yang mudah untuk proses backup } \\
\text { dan restore. } \\
\text { Memudahkan pengaksesan data secara terintegrasi } \\
\text { untuk mempercepat pelayanan dan pengambilan } \\
\text { keputusan. }\end{array}$ \\
\hline 3. & $\begin{array}{l}\text { Aplikasi yang mudah digunakan dan saling } \\
\text { terintegrasi }\end{array}$ & $\begin{array}{l}\text { - Meningkatkan efektifitas proses bisnis (aktivitas) } \\
\text { dan efisiensi sumber daya. } \\
\text { - Memudahkan dalam pemrosesan data pada aplikasi } \\
\text { untuk meningkatkan kualitas pelayanan. }\end{array}$ \\
\hline 4. & Perangkat komunikasi dan jaringan & $\begin{array}{l}\text { - Teknologi komunikasi mampu mendukung } \\
\text { perkembangan teknologi di masa mendatang. } \\
\text { - Jaringan yang dibangun mempunyai bandwidth } \\
\text { yang memadai untuk akses real time terhadap } \\
\text { informasi dan beragam format data. }\end{array}$ \\
\hline
\end{tabular}

\subsection{Architecture Vision (Phase A)}

Fase arsitektur visi ini bertujuan untuk mendefinisikan ruang lingkup, menentukan seluruh aktivitas menggunakan analisis value chain diagram, mengidentifikasi permasalahan dan solusi pada setiap aktivitas, mengidentifikasi stakeholder, menentukan struktur organisasi usulan, serta mendefinisikan hubungan keterlibatan stakeholder pada SMK Kesehatan Hidayah Medika Tasikmalaya [3]. Berikut ini Gambar 1. Merupakan hasil analisis dari seluruh aktivitas di SMK Kesehatan Hidayah Medika Tasikmalaya yang dimodelkan kedalam Value Chain Diagram. Analisis value chain diagram bertujuan untuk menggambarkan dan mengelompokkan seluruh aktivitas di SMK Kesehatan Hidayah Medika Tasikmalaya. Pengelompokkan aktivitas pada value chain diagram tersebut memiliki dua jenis kelompok, yaitu aktivitas utama dan aktivitas pendukung [11]. 


\begin{tabular}{|c|c|c|c|c|c|}
\hline \multirow{4}{*}{ 递 } & \multicolumn{2}{|c|}{ Pendukung infrastruktur } & \multicolumn{3}{|c|}{ : Pengelolaan keuangan } \\
\hline & \multicolumn{2}{|c|}{ Manajemen sumber daya manusia } & \multicolumn{3}{|c|}{ : Pengelolaan kepegawaian } \\
\hline & \multicolumn{2}{|c|}{ Pengembangan teknologi } & \multicolumn{3}{|l|}{ :Pengelolaan TIK } \\
\hline & \multicolumn{2}{|l|}{ Pengadaan barang } & \multicolumn{3}{|c|}{ : Pengelolaan sarana prasarana } \\
\hline \multirow{3}{*}{ 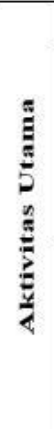 } & Masukan & Pengelolaan & Keluaran & Pemasaran & Layanan \\
\hline & $\begin{array}{l}\text { Penerimaan } \\
\text { peserta didik baru }\end{array}$ & $\begin{array}{l}\text { - Kegiatan } \\
\text { akademik } \\
\text { - Kegiatan non } \\
\text { akademik }\end{array}$ & $\begin{array}{l}\text { - Perpisahan } \\
\text { siswa } \\
\text { - Publikasi } \\
\text { prestasi siswa }\end{array}$ & $\begin{array}{l}\text { - Sosialisasi ke } \\
\text { SMP } \\
\text { - Promosi melalui } \\
\text { media cetak dan } \\
\text { elektronik }\end{array}$ & $\begin{array}{l}\text { - Bimbingan konseling } \\
\text { - Laboratorium } \\
\text { - Perpustakaan } \\
\text { - Penelusuran alumni }\end{array}$ \\
\hline & $\begin{array}{l}\text { Pengajuan dan } \\
\text { penandatanganan } \\
\text { kerja sama }\end{array}$ & $\begin{array}{l}\text { - Kerja sama } \\
\text { melalui program } \\
\text { Prakerin } \\
\text { - Recruitment } \\
\text { alumni }\end{array}$ & $\begin{array}{l}\text { Penyaluran tenaga } \\
\text { kerja bagi alumni }\end{array}$ & Promosi & Bursa kerja khusus \\
\hline
\end{tabular}

Gambar 1. Value Chain Diagram SMK Kesehatan Hidayah Medika Tasikmalaya

Aktivitas di SMK Kesehatan Hidayah Medika Tasikmalaya yang termasuk ke dalam aktivitas utama dalam analisis value chain diagram adalah sebagai berikut:

a) Penerimaan peserta didik baru dapat dideskripsikan sebagai semua proses kegiatan yang berkaitan dengan penerimaan peserta didik baru, seleksi peserta didik baru sampai diterimanya peserta didik baru menjadi siswa tetap.

b) Kegiatan akademik dapat dideskripsikan sebagai semua proses yang berkaitan dengan kegiatan belajar mengajar melalui proses kurikulum yang telah ditetapkan.

c) Kegiatan non akademik dapat dideskripsikan sebagai proses yang berkaitan dengan siswa dibidang nonakademik, yang terdiri dari program-program kesiswaan atau ekstra kurikuler.

d) Perpisahan siswa dapat dideskripsikan sebagai proses pelaksanaan perpisahan siswa yang telah dinyatakan lulus mengikuti kegiatan belajar mengajar selama tiga tahun serta ujian akhir yaitu UAS dan UN.

e) Publikasi prestasi siswa dapat dideskripsikan sebagai proses yang berkaitan dengan sarana publikasi prestasi siswa yang diraih baik itu prestasi akademik maupun non akademik.

f) Sosialisasi ke SMP dapat dideskripsikan sebagai proses untuk menjalin komunikasi dengan sekolahsekolah menengah pertama (SMP) terutama kepada siswa yang akan melanjutkan ke jenjang berikutnya, dan memperkenalkan ruang lingkup SMK Kesehatan Hidayah Medika Tasikmalaya.

g) Promosi melalui media cetak dan elektronik dapat dideskripsikan sebagai proses untuk memperkenalkan ruang lingkup SMK Kesehatan Hidayah Medika Tasikmalaya secara jelas kepada masyarakat umum melalui media cetak dan elektronik.

h) Bimbingan konseling dapat dideskripsikan sebagai proses dalam usaha untuk memberikan pelayanan tambahan bagi siswa berupa bimbingan secara intens baik itu bimbingan terhadap keluhan atau permasalahan yang dialami siswa, kasus siswa, karir siswa dan lanjutan pendidikan siswa.

i) Laboratorium dapat dideskripsikan sebagai proses yang berkaitan dengan usaha untuk mengelola seluruh operasional laboratorium seperti proses pengadaan, penyimpanan, pemeliharaan dan penggunaan alat-alat laboratorium, pemeliharaan ruangan laboratorium, serta pelaksanaan praktikum siswa di laboratorium.

j) Perpustakaan dapat dideskripsikan sebagai proses yang berkaitan dengan usaha untuk mengelola seluruh operasional perpustakaan seperti proses pengadaan, penyimpanan, pemeliharaan, dan perbaikan buku perpustakaan, proses pendaftaran anggota perpustakaan, proses peminjaman serta pengembalian buku perpustakaan.

k) Penelusuran alumni dapat dideskripsikan sebagai proses yang berkaitan dengan kegiatan pendataan siswa yang telah lulus dan pendataan karir atau lanjutan pendidikan alumni.

1) Pengajuan dan penandatanganan kerja sama dapat dideskripsikan sebagai proses permintaan atau negosiasi untuk menjalin kerja sama dari kedua belah pihak serta pengesahan menjadi mitra dengan bukti penandatanganan surat kerja sama.

m) Kerja sama melalui program Prakerin dapat dideskripsikan sebagai proses yang berkaitan dengan usaha untuk memperkenalkan dunia kerja kepada siswa, mengembangkan keterampilan siswa dalam bentuk kerja nyata industri yang diharapkan dapat memberikan keuntungan bagi industri untuk membantu operasional, dan siswa untuk memenuhi kebutuhan pembelajaran.

n) Recruitment alumni dapat dideskripsikan sebagai proses seleksi untuk mendapatkan alumni dengan kompetensi yang dimiliki memadai dan sesuai dengan standar kebutuhan industri, baik secara knowledge skills maupun attitude. 
o) Penyaluran tenaga kerja bagi alumni merupakan proses menindaklanjuti kerja sama dan proses selanjutnya untuk disalurkan di dunia kerja bagi alumni yang telah berhasil lolos melaksanakan seleksi dari pihak industri terkait.

p) Promosi dapat dideskripsikan sebagai proses untuk meningkatkan pemasaran bagi keuntungan kedua belah pihak yang melaksanakan kerja sama.

q) Bursa kerja khusus dapat dideskripsikan sebagai proses yang berkaitan dengan kegiatan untuk memberikan pelayanan dan informasi lowongan kerja, melaksanakan pemasaran, penyaluran, dan penempatan tenaga kerja.

Aktivitas di SMK Kesehatan Hidayah Medika Tasikmalaya yang termasuk ke dalam aktivitas pendukung dalam analisis value chain diagram adalah sebagai berikut:

a) Pengelolaan keuangan berkaitan dengan kegiatan untuk mengelola seluruh operasional pembiayaan sekolah, pemasukan dan pengeluaran bulanan-tahunan di SMK Hidayah Medika Tasikmalaya.

b) Pengelolaan kepegawaian berkaitan dengan kegiatan pendukung untuk menentukan kebutuhan, memantau dan melakukan alokasi sumber daya pada aktivitas bisnis di SMK Hidayah Medika Tasikmalaya.

c) Pengelolaan TIK berkaitan dengan kegiatan untuk memberikan dukungan terhadap pengembangan, pemanfaatan, dan pengelolaan SI/TI dalam membantu kinerja operasional di SMK Hidayah Medika Tasikmalaya agar lebih efisien.

d) Pengelolaan sarana prasarana berkaitan dengan kegiatan untuk melakukan pengadaan sarana dan prasarana yang dibutuhkan untuk mendukung semua proses bisnis di SMK Hidayah Medika Tasikmalaya.

Aktivitas pada value chain diagram yang telah melalui proses pengamatan dan analisis didapatkan beberapa permasalahan yang dialami oleh SMK Kesehatan Hidayah Medika Tasikmalaya yaitu:

a) Informasi yang dikelola sekolah masih bersifat manual, sehingga proses pengerjaan membutuhkan waktu yang cukup lama.

b) Belum tersedia sistem informasi yang saling terintegrasi untuk mengatur seluruh aktivitas yang dapat mendukung kinerja.

c) Sistem pengelolaan data yang hanya menggunakan software Microsoft Office, sehingga memberi dampak pada aktivitas transfer data yang kurang efisien dan keamanan data yang kurang terjamin.

d) Ketersediaan Hardware yang belum memadai, sehingga menyebabkan terhambatnya proses ketatausahaan, pelayanan, dan kegiatan belajar mengajar.

e) Penggunaan koneksi internet masih terbatas, yang menyebabkan tidak adanya fasilitas koneksi internet untuk memenuhi kebutuhan belajar bagi siswa.

Berdasarkan permasalahan yang telah diidentifikasi, maka didapatkan solusi yang diusulkan. Solusi usulan tersebut dilihat dari alur kerja agar prosesnya menjadi lebih baik yaitu:

a) Mengarahkan pengelolaan kegiatan sekolah kepada berbasis IT untuk lebih membantu optimalisasi kerja.

b) Menyediakan fasilitas sistem informasi yang saling terintegrasi pada setiap aktivitas. Hal tersebut dapat memudahkan dalam pengelolaan data untuk meningkatkan kualitas pelayanan dan memudahkan melakukan akses data secara bersamaan untuk mempercepat proses pelayanan serta pengambilan keputusan.

c) Merancang arsitektur software yang dibangun secara khusus yaitu berbasis web untuk sistem pengelolaan data dan transfer data pada setiap aktivitas, dengan hak akses data yang dibatasi sesuai kebutuhan pengguna.

d) Menentukan skala prioritas pengadaan hardware yang diperlukan untuk menyediakan fasilitas hardware sesuai dengan kebutuhan proses aktivitas bisnis.

e) Menyediakan fasilitas koneksi internet dengan membangun jaringan yang mempunyai bandwidth yang memadai, serta mengatur bandwidth bagi setiap tingkatan pengguna.

Struktur organisasi usulan dihasilkan dari analisis value chain diagram. Berdasarkan analisis value chain diagram yang sudah dilakukan dan melihat dari struktur organisasi yang ada, SMK Kesehatan Hidayah Medika Tasikmalaya belum memiliki bagian khusus untuk lebih fokus dalam menangani implementasi arsitekturarsitektur yang akan dibuat dan bagian perpustakaan untuk meningkatkan pelayanan bagi siswa dalam mendukung proses belajar mengajar. Maka dalam proses tersebut peran bagian TI dan pustakawan sangat diperlukan untuk menunjang implementasi arsitektur.

\subsection{Architecture Business (Phase B)}

Fase arsitektur bisnis ini bertujuan untuk menentukan model aktivitas dengan tahapan yang dilakukan yaitu melakukan analisis peran setiap stakeholder yang digambarkan dalam Analisis Actor/Role Matrix [3] dengan peranan sebagai berikut yaitu Responsible (R), Accountable (A), Consulted (C), dan Informed (I). Analisis tersebut digunakan untuk menggambarkan pemodelan aktivitas berdasarkan aktivitas yang sedang berjalan dan 
analisis value chain yang ada di SMK Kesehatan Hidayah Medika Tasikmalaya. Berikut ini salah satu contoh arsitektur bisnis yang dirancang menggunakan Business Process Model and Notation (BPMN) yaitu pada aktivitas Promosi melalui Media Cetak dan Elektronik tertera pada Gambar 2. Aktivitas promosi melalui media cetak dan elektronik dapat dideskripsikan sebagai proses untuk memperkenalkan ruang lingkup SMK Kesehatan Hidayah Medika Tasikmalaya secara jelas kepada masyarakat umum melalui media cetak (brosur, spanduk, koran, dan lain-lain) serta media elektronik (website dan media sosial lainnya).

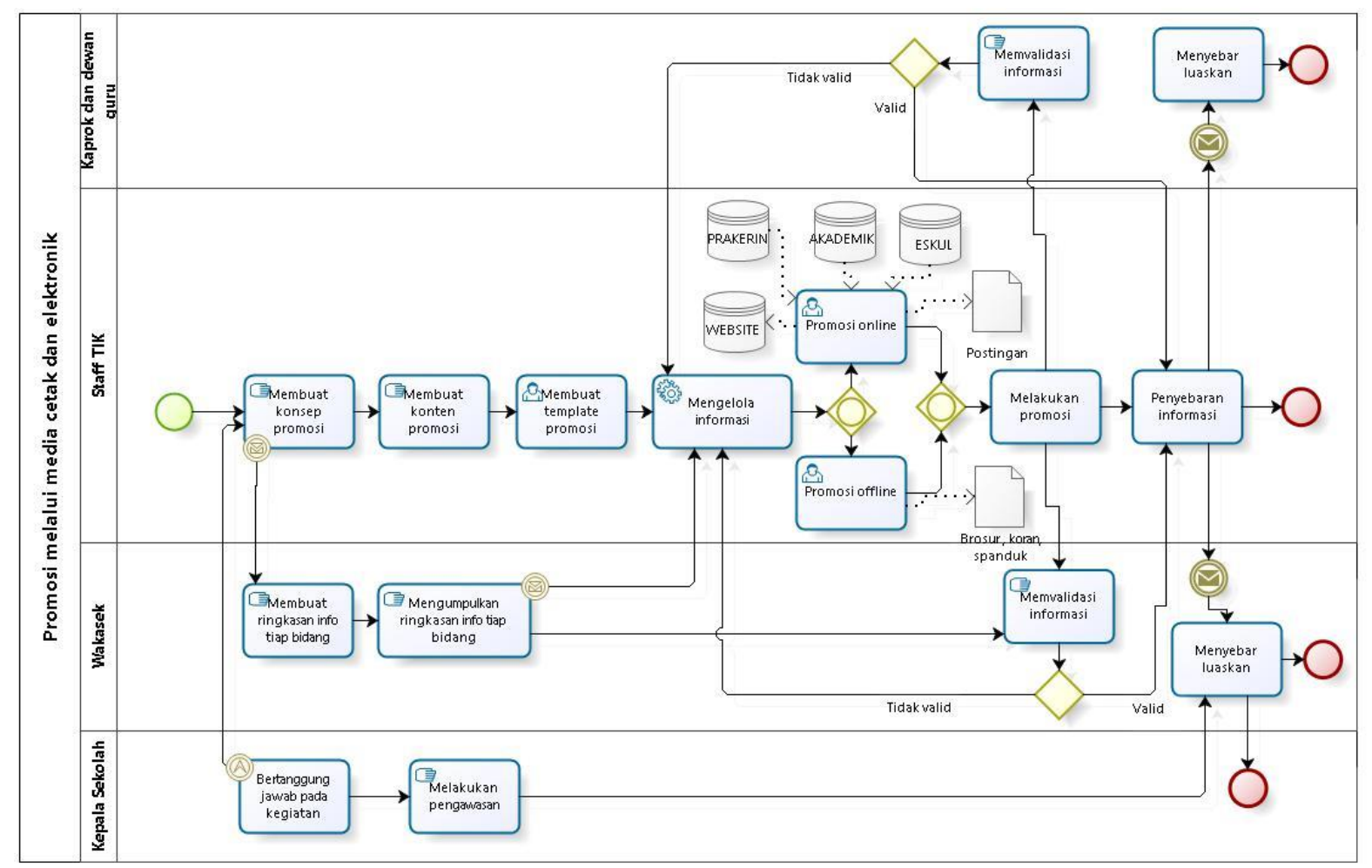

Gambar 2. Business Process Model and Notation pada Aktivitas Promosi Melalui Media Cetak dan Elektronik

\subsection{Information System Architecture (Phase C)}

Fase arsitektur sistem informasi ini bertujuan untuk menentukan bagaimana membangun arsitektur aplikasi dan arsitektur data pada SMK Kesehatan Hidayah Medika Tasikmalaya [3].

\subsubsection{Application Architecture}

Tahapan yang dilakukan pada fase ini yaitu mengidentifikasi dan menentukan aplikasi-aplikasi yang dibutuhkan SMK Kesehatan Hidayah Medika menggunakan Application Portfolio Catalog serta menggambarkan persyaratan fungsional aplikasi menggunakan Use Case Diagram [3]. Berikut ini Application Portfolio Catalog untuk kebutuhan SMK Kesehatan Hidayah Medika Tasikmalaya.

a) Sistem Informasi Manajemen Penerimaan Peserta Didik Baru (SIM PPDB), berfungsi sebagai pusat layanan penerimaan peserta didik baru di SMK Kesehatan Hidayah Medika Tasikmalaya. Informasi yang disediakan dari mulai bagaimana informasi tentang sekolah, alur dan penjadwalan penerimaan peserta didik baru, melaksanakan pendaftaran, melaksanakan ujian, sampai siswa dinyatakan diterima dan sah menjadi siswa SMK dengan tanda bukti kartu pelajar.

b) Sistem Informasi Manajemen Akademik (SIMAK), berfungsi sebagai pusat layanan akademik di SMK Kesehatan Hidayah Medika Tasikmalaya. Pelayanan tersebut adalah mengelola penjadwalan, pembagian wali kelas, daftar guru pelajaran, mengelola kegiatan

belajar mengajar, mengelola administrasi pembelajaran, mengelola nilai siswa (ulangan harian, ulangan tengah semester, ulangan akhir semester, ujian nasional, ujian prakerin), menentukkan standar KKM dan kelulusan siswa, sampai melakukan pencetakkan raport bagi siswa,

serta pelaporan secara berkala dengan penggambaran statistik selama proses kegiatan belajar mengajar berlangsung.

c) Sistem Informasi Manajemen Praktek Kerja Industri (SIM Prakerin), berfungsi untuk mengelola seluruh aktivitas Prakerin dan memberikan pelayanan yang berhubungan dengan prakerin baik itu untuk internal sekolah maupun eksternal sekolah. Pelayanan tersebut dapat membantu pihak sekolah untuk mengelola 
administrasi prakerin siswa, membantu siswa dalam memonitoring hasil kegiatannya selama melaksanakan Prakerin, dan membantu pihak kemitraan untuk memperkenalkan dunia kerja secara nyata kepada siswa

d) Sistem Informasi Manajemen Ekstra Kurikuler (SIM ESKUL), berfungsi sebagai pusat pelayanan yang berhubungan dengan kegiatan non akademik, yaitu ekstra kurikuler (eskul). Sistem ini dapat mempermudah proses recruitment siswa sesuai dengan minat dan bakatnya. Dimana siswa dapat mengembangkan passionnya masing-masing melalui eskul yang dipilihnya. Selain itu, sistem ini dapat membantu pihak sekolah untuk mengelola eskul, administrasi eskul, dan informasi eskul lainnya.

e) Website berfungsi sebagai pusat layanan informasi sekolah. Informasi yang disediakan yaitu kegiatankegiatan sekolah baik itu akademik/non akademik, prestasi siswa yang telah diraih, berita-berita internal/eksternal yang berkaitan dengan sekolah, artikel-artikel kesehatan, dan siswa dapat memberikan kritik serta saran untuk kelancaran kegiatan di sekolah.

f) Sistem Informasi Manajemen Konseling (SIM Konseling), berfungsi sebagai pusat pengelolaan dan pelayanan yang berhubungan dengan konseling terhadap siswa. Sistem ini mengelola program bimbingan yang dapat diikuti oleh seluruh siswa terkait bimbingan psikologi, penyuluhan, karir, dan lanjutan pendidikan. Selain itu, guru BP dan Wali kelas dapat menangani kasus siswa baik itu laporan inisiatif sendiri dari siswa atau melaporkan kasus siswa lain. Ketika laporan kasus yang begitu berat, sistem ini akan melaporkan kepada wali siswa untuk dapat menangani bersama dan mengontrol anaknya.

g) Sistem Informasi Manajemen Perpustakaan (SIM Perpus), berfungsi sebagai pusat pengelolaan dan pelayanan yang berhubungan dengan perpustakaan yang ada di sekolah. Sistem ini mengelola siswa SMK yang menjadi anggota perpustakaan, mengelola buku (pengadaan dan ketersediaan buku), mengelola absensi buku tamu untuk mengetahui antusias siswa terhadap baca buku di perpustakaan, transaksi peminjaman dan pengembalian buku, pembuatan label buku serta pembuatan kartu anggota perpustakaan.

h) Sistem Informasi Manajemen Laboratorium (SIMLAB), berfungsi sebagai pengelolaan terkait laboratorium baik itu laboratorium kesehatan sesuai dengan bidang kompetensi keahlian maupun laboratorium komputer. Pengelolaan yang dilakukan yaitu jadwal penggunaan laboratorium, aktivitas apa saja yang dilakukan di laboratorium, pelaporan kondisi dan ketersediaan alat-alat laboratorium, simulasi-simulasi kesehatan serta simulasi untuk menghadapi ujian akhir semester atau ujian nasional berbasis komputer.

i) Sistem Informasi Manajemen Bursa Kerja Khusus Alumni (SIMBKK Alumni), berfungsi sebagai pusat pengelolaan dan pelayanan bagi alumni yang berkaitan dengan Bursa Kerja Khusus. Sistem ini dimulai dari mendata alumni-alumni; karir yang sedang dijalani alumni apakah melanjutkan ke jenjang pendidikan, bekerja atau tidak bekerja; mengelola kerja sama dengan pihak DU/DI (Dunia Usaha/Dunia Industri) yang sudah menjadi mitra; mengelola lowongan pekerjaan bagi alumni baik dari DU/DI atau dari jaringan job carrier; melakukan pelatihan dan bimbingan keterampilan bagi alumni; menyalurkan calon tenaga kerja; memonitoring kinerja alumni yang sudah mendapatkan pekerjaan; serta mengelola pelaporan kegiatan. Selain itu, alumni dapat memberikan saran dan kritiknya.

j) Aplikasi Surat Masuk dan Surat Keluar berfungsi untuk membuat, mengelola, serta mengarsipkan surat masuk dan surat keluar beserta disposisi yang akan dikeluarkan.

k) Aplikasi Keuangan berfungsi untuk mempermudah pengelolaan seluruh aktivitas keuangan sekolah.

1) Aplikasi Dapodik (Data Pokok Pendidik), berfungsi untuk alokasi dana BOS bagi sekolah, alokasi kuota penerima tunjangan-tunjangan bagi guru, alokasi bantuan sarana prasarana, pengajuan dan perbaikan data kelembagaan, pengajuan dan Verval siswa \& NISN, pemetaan dan pemerataan guru, monitoring dan evaluasi kebijakan \& program kemendikbud, mempercepat dan meningkatkan efektifitas pelaporan, serta mengurangi resiko penyimpangan atau pelanggaran

Berikut ini salah satu contoh pada Gambar 3. arsitektur aplikasi yang dirancang menggunakan Use Case Diagram berdasarkan Application Portfolio Catalog yang telah diidentifikasi, yaitu aplikasi Website. 


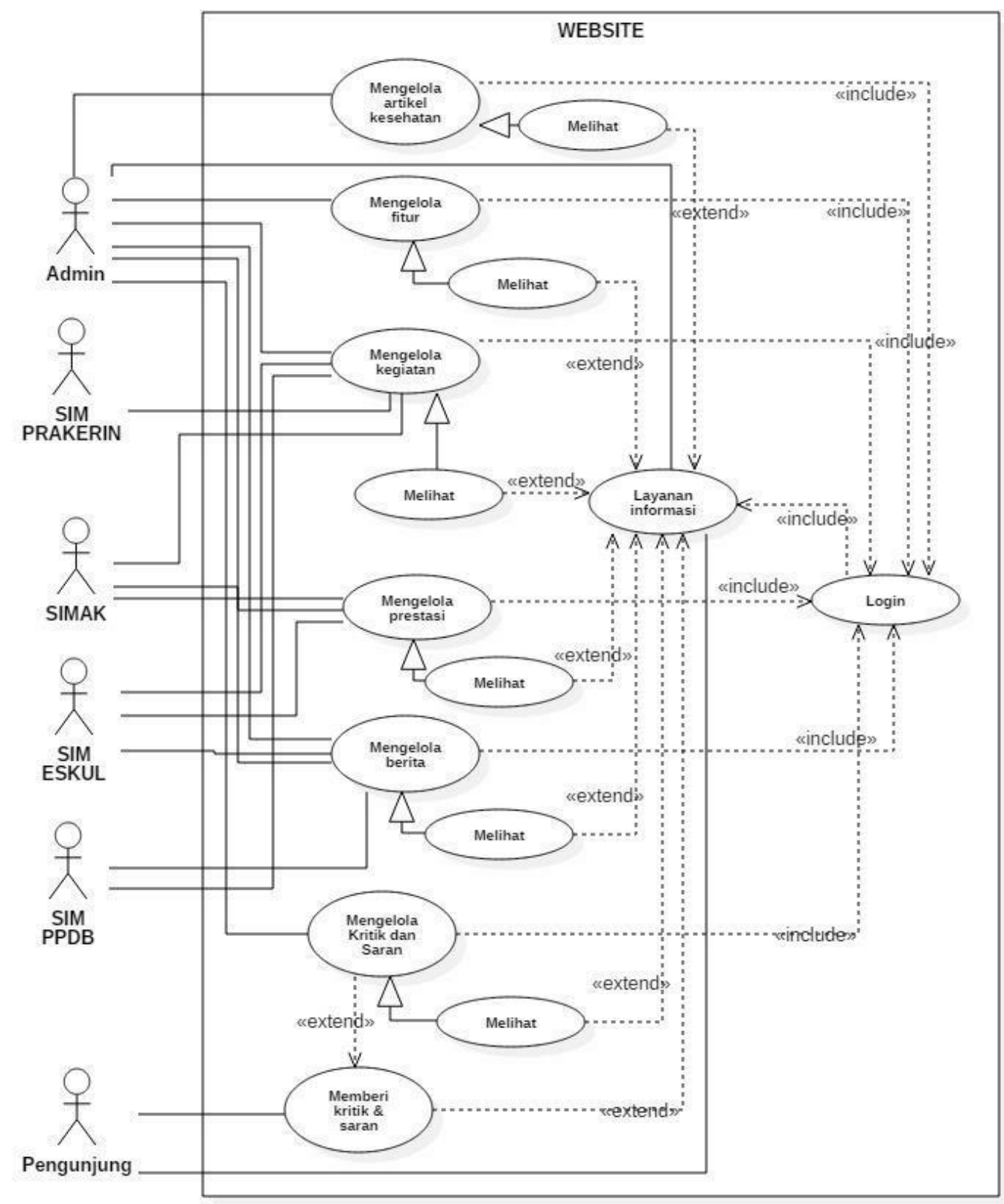

Gambar 3. Use Case Diagram Website

\subsubsection{Data Architecture}

Tahapan yang dilakukan pada fase ini yaitu mengidentifikasi dan menentukan pemodelan data-data pada aplikasi yang digunakan untuk menghasilkan informasi yang dibutuhkan oleh SMK Kesehatan Hidayah Medika Tasikmalaya menggunakan Class Diagram [3]. Berikut ini salah satu contoh arsitektur data yang dirancang menggunakan Class Diagram pada aplikasi Website, tertera pada Gambar 4. 


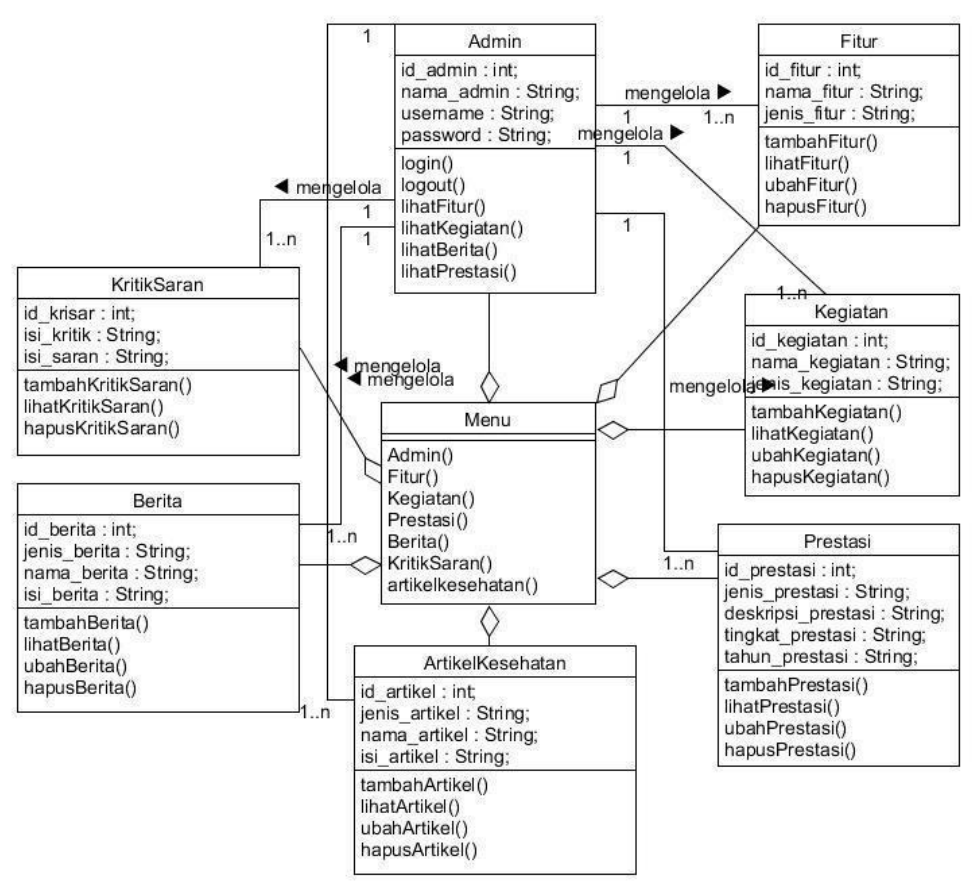

Gambar 4. Class Diagram Website

\subsection{Technology Architecture (Phase D)}

Fase arsitektur teknologi ini bertujuan untuk menggambarkan struktur teknologi yang dibutuhkan oleh SMK Kesehatan Hidayah Medika Tasikmalaya. Tahapan ini mengidentifikasi infrastruktur terhadap jaringan, teknologi pada hardware dan software yang tersedia. Hal tersebut bertujuan untuk membuat infrastruktur jaringan usulan yang lebih efektif dan efisien menggunakan Communication Engineering Diagram, platform teknologi menggunakan Platform Decomposition Diagram, dan daftar teknologi yang digunakan sesuai dengan kebutuhan menggunakan Technology Portfolio Catalog [3]. Berikut ini merupakan gambaran infrastruktur jaringan saat ini di SMK Kesehatan Hidayah Medika Tasikmalaya tertera pada Gambar 5.

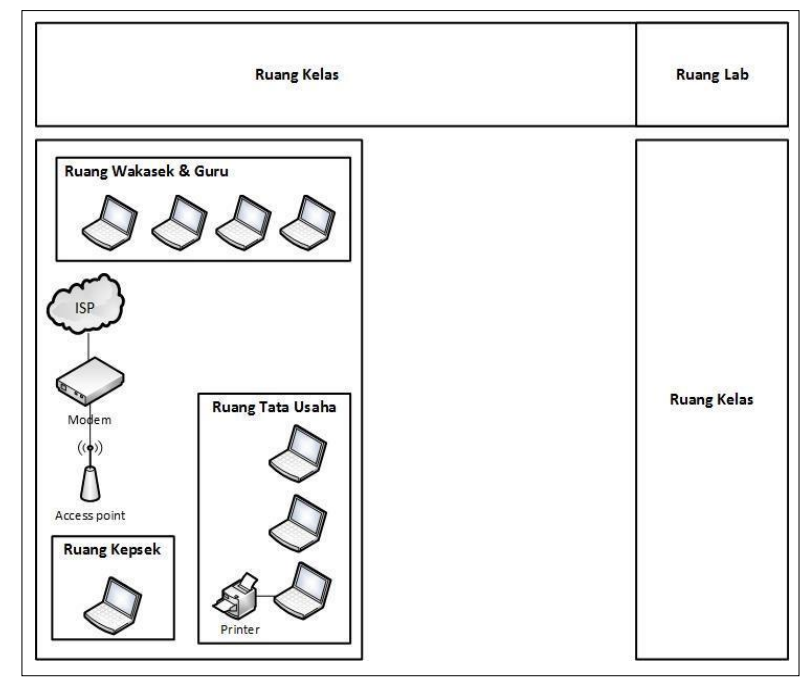

\section{Gambar 5. Infrastruktur Jaringan saat ini pada SMK Kesehatan Hidayah Medika Tasikmalaya}

Penggunaan koneksi internet pada Gambar 5. masih terbatas hanya untuk Kepala Sekolah, Staff Tata Usaha, Wakasek, dan Guru dengan tujuan untuk memaksimalkan proses transfer data dalam memenuhi kebutuhan ketatausahaan dan hal lainnya yang berhubungan dengan kepentingan sekolah. Pembatasan penggunaan koneksi internet tersebut menyebabkan tidak adanya fasilitas koneksi internet untuk memenuhi kebutuhan bagi siswa dalam mendukung proses pembelajaran. Berikut ini merupakan gambaran infrastruktur jaringan usulan di SMK Kesehatan Hidayah Medika Tasikmalaya tertera pada Gambar 6. 


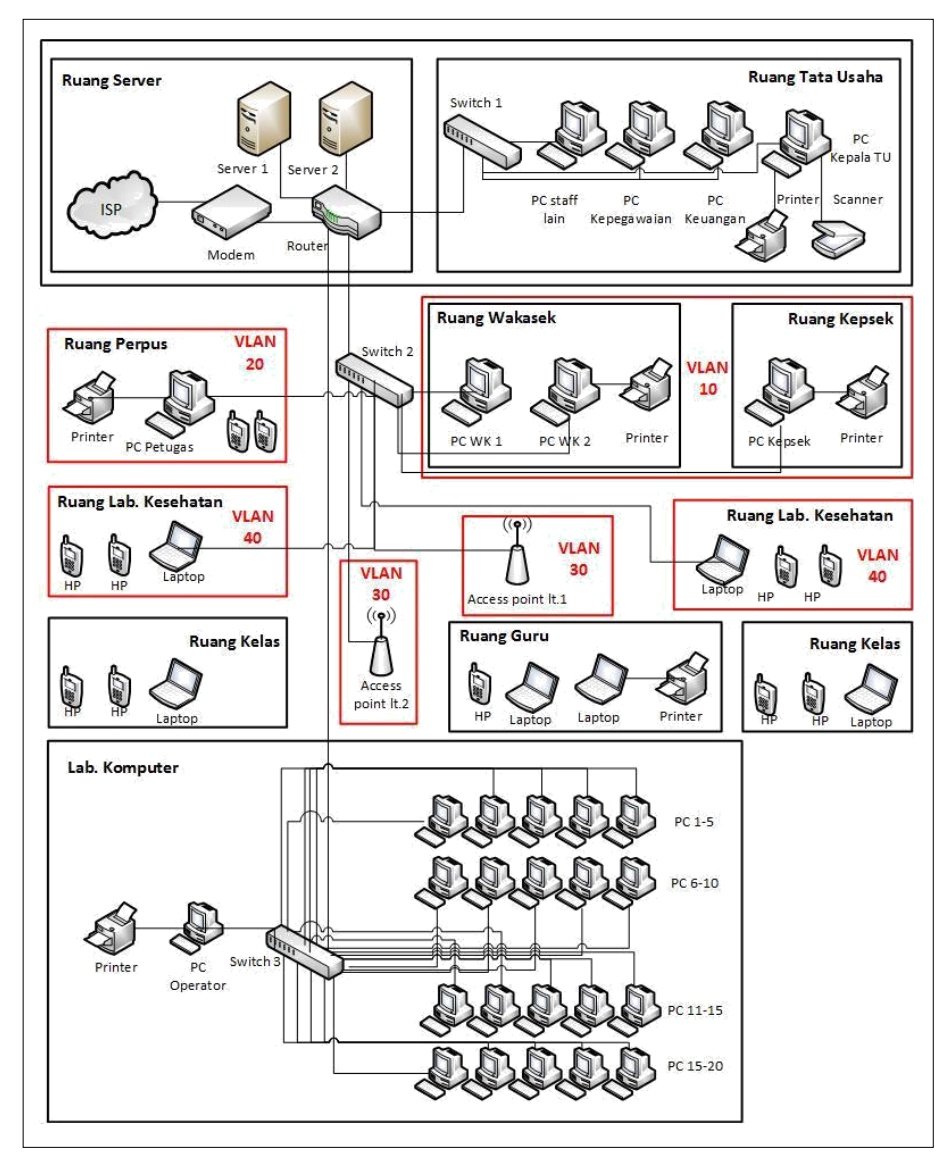

Gambar 6. Infrastruktur Jaringan Usulan pada SMK Kesehatan Hidayah Medika Tasikmalaya

Infrastruktur jaringan usulan pada Gambar 6. disesuaikan dengan kebutuhan dan arsitektur sistem informasi yang telah dirancang. Area jaringan dibagi menjadi dua area, yaitu area lantai satu yang terdiri dari Ruang Server, Ruang Tata Usaha, Ruang Kepala Sekolah, Ruang Wakasek, Ruang Guru, Ruang Laboratorium Kesehatan dan Ruang Kelas. Serta area lantai dua yang terdiri dari Ruang Perpustakaan, Ruang Kelas, Ruang Laboratorium Kesehatan dan Ruang Laboratorium Komputer.

Jaringan usulan terdiri dari tiga jenis jaringan yaitu Internet, LAN (Local Area Network), dan VLAN (Virtual Local Area Network). Aktivitas yang dilakukan oleh seluruh pengguna dengan mengakses sistem informasi yang telah dirancang melalui jaringan Internet, LAN, dan VLAN akan dikirimkan ke server. Adanya server sebagai database server dan web server menjadikan sistem informasi dapat saling terintegrasi untuk memudahkan pengelolaan data dan pengaksesan data secara bersamaan dalam meningkatkan kualitas pelayanan sekolah.

Berikut ini spesifikasi hardware dan software yang akan digunakan pada infrastruktur jaringan usulan untuk SMK Kesehatan Hidayah Medika Tasikmalaya tertera pada Tabel 3 untuk Client-Server pelayanan dan Tabel 4 untuk Client-Server Lab. Komputer.

Tabel 3. Spesifikasi Hardware dan Software Client-Server Pelayanan

\begin{tabular}{ll}
\hline \multicolumn{1}{c}{ Server } & \multicolumn{1}{c}{ Client } \\
\hline Prosesor: Xeon E3 & Prosesor: Core i3 \\
RAM: 16 GB DDR3 & RAM: 4 GB DDR 3 \\
Hardisk: 1 TB & Hardisk: 500 GB \\
Input device: Mouse, Keyboard & Input device: Mouse, Keyboard, Scanner \\
Output device: Monitor, Printer & Output device: Monitor, Printer \\
LAN Card (NIC) 1000 Mbps & LAN Card 100 Mbps \\
Operating System (64 bit) Windows Server 2012 & Operating System (64 bit): Windows 7 \\
Processing: Microsoft office 2016 & Processing: Microsoft office 2016 \\
Database Server: MySQL & Web browser: Mozilla firefox, Chrome, dll. \\
Web Server: Apache versi 2.4 & - \\
Bahasa pemrograman: PHP 7.2, HTML 5, dll & - \\
\hline
\end{tabular}


Tabel 4. Spesifikasi Hardware dan Software Client-Server Lab. Komputer

\begin{tabular}{ll}
\hline \multicolumn{1}{c}{ Server } & \multicolumn{1}{c}{ Client } \\
\hline Prosesor Core i5 & Prosesor Intel Celeron \\
RAM 8 GB DDR3 & RAM 2 GB DDR 3 \\
Hardisk 500 GB & Hardisk 250 GB \\
Input device: Mouse, Keyboard & Input device: Mouse, Keyboard \\
Output device: Monitor, Printer & Output device: Monitor, Earphone/Headset \\
LAN Card (NIC) 1000 Mbps & LAN Card 100 Mbps \\
Operating System (64 bit) & Operating System (64 bit): \\
Windows Server 2012 & Windows 7 \\
Web browser: Mozilla firefox, Chrome, dll. & Web browser: Exambro dan Chrome \\
\hline
\end{tabular}

Platform Technology yang mendukung operasional SI/TI bertujuan untuk menggambarkan seluruh sistem yang diusulkan, bahwa sistem yang di usulkan sudah berbasis web. Level client interface terbagi menjadi dua bagian yaitu user eksternal dan user internal. User eksternal dapat mengakses aplikasi Website dan SIM PPDB melalui tools web browser dan jaringan internet. Sedangkan user internal dapat mengakses seluruh sistem aplikasi yang telah dirancang melalui tools web browser, jaringan internet, jaringan lokal (LAN), dan VLAN. Apache web server digunakan untuk mendukung berjalannya aplikasi berbasis web. Aplikasi berbasis web dibangun menggunakan bahasa pemrograman PHP (Hypertext Preprocessor). Bahasa pemrograman ini akan mengambil data dari masing-masing data storage.

Berdasarkan arsitektur teknologi yang telah dirancang, maka dapat diidentifikasi daftar infrastruktur hardware, software, dan jaringan yang dimodelkan melalui Technology Portfolio Catalog yaitu tertera pada Gambar 7.

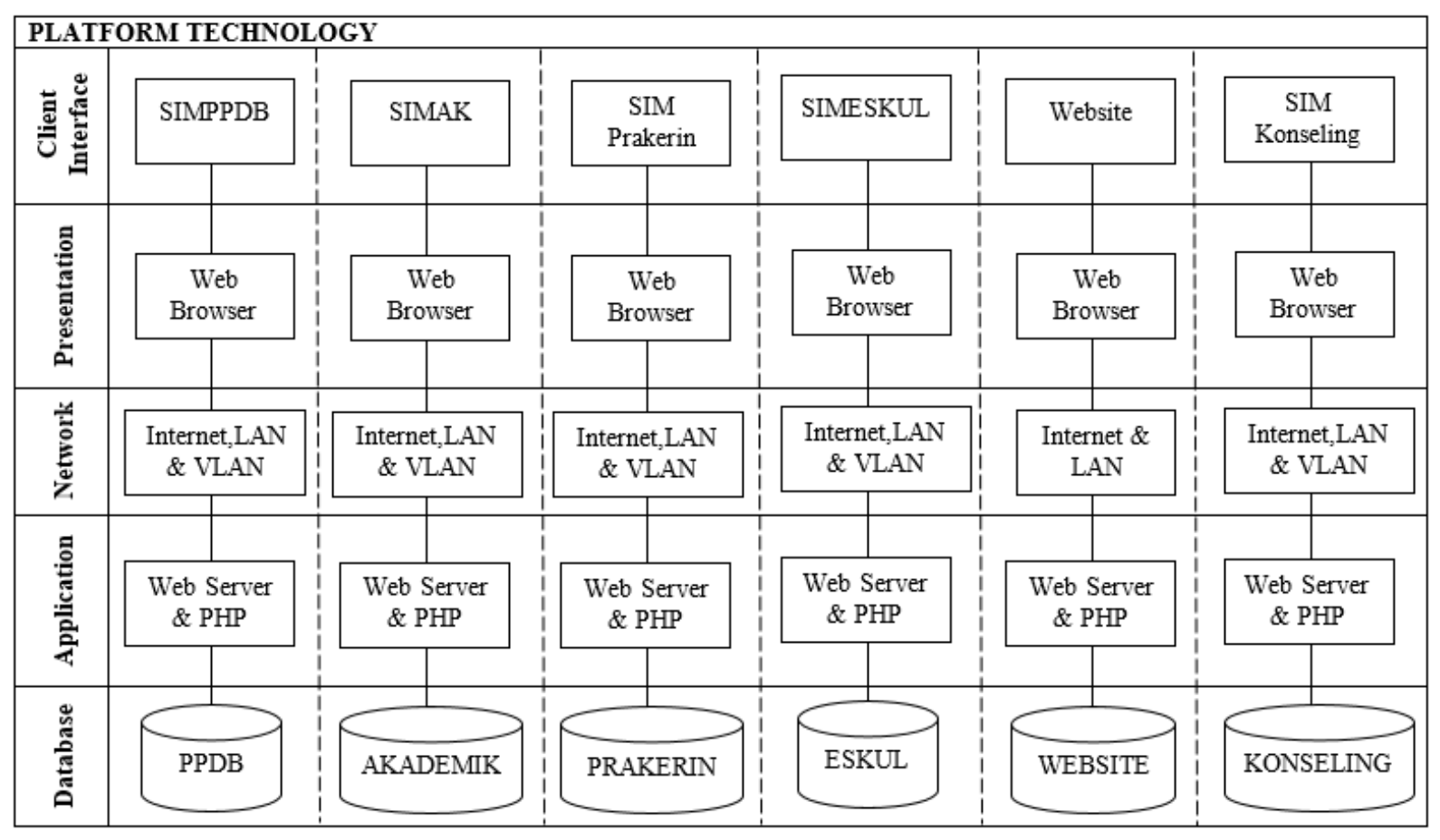

Gambar 7. Technology Portfolio Catalog 


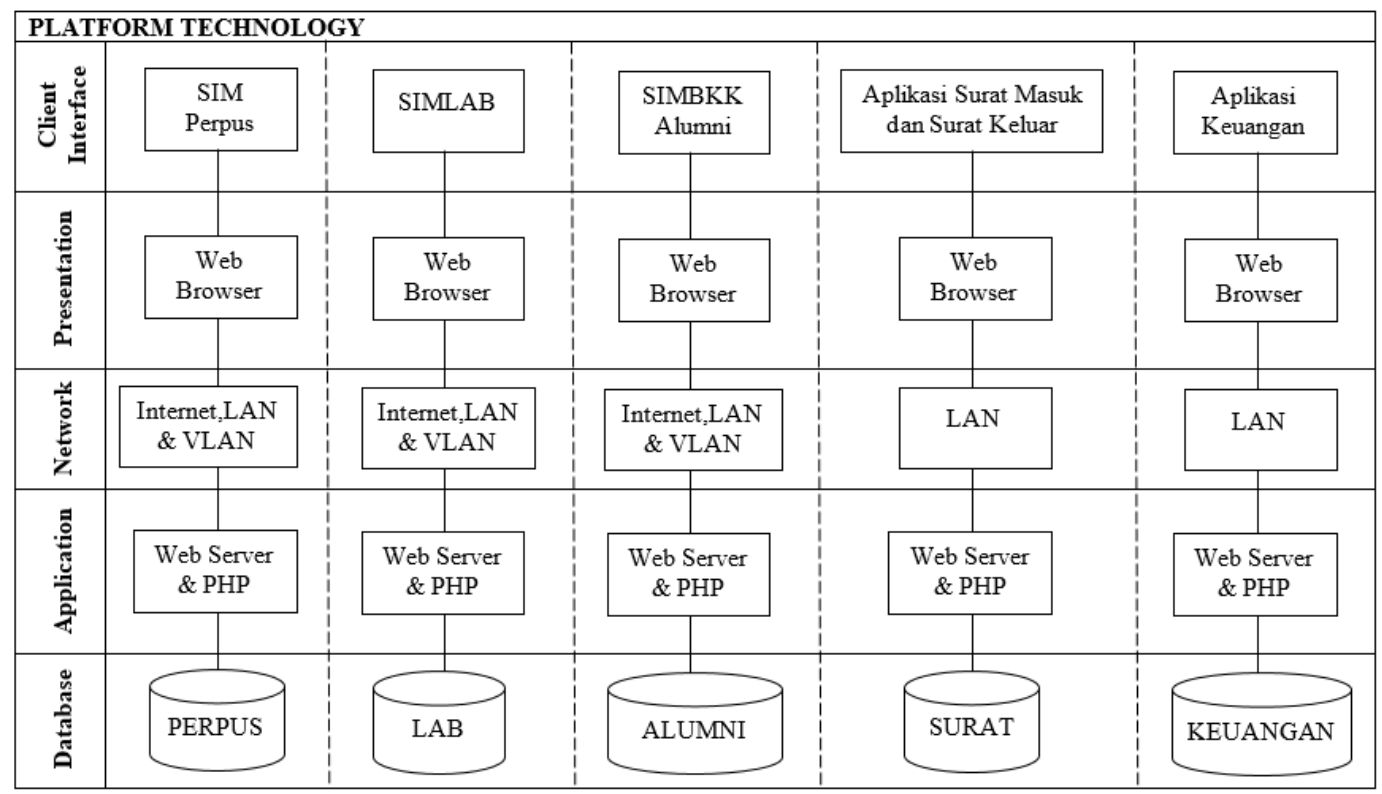

Gambar 7. Technology Portfolio Catalog (lanjutan)

\subsection{Opportunities and Solutions (Phase E)}

Fase ini bertujuan untuk melakukan evaluasi model-model arsitektur pada fase arsitektur bisnis, aplikasi, data, dan teknologi yang telah dirancang sesuai kondisi SMK Kesehatan Hidayah Medika Tasikmalaya menggunakan Matrix Analysis Gap serta menggambarkan Roadmap implementasi arsitektur SI/TI [3] berdasarkan pemetaan portofolio aplikasi menggunakan analisis McFarlan Strategic Grid [12]. Berikut salah satu contoh Matrix Gap Analysis yaitu tertera pada Gambar 8, yang merupakan analisis gap dari arsitektur aplikasi.

\begin{tabular}{|c|c|c|c|c|c|c|c|c|c|c|c|c|c|}
\hline Existing & 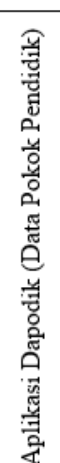 & 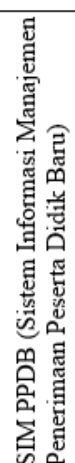 & 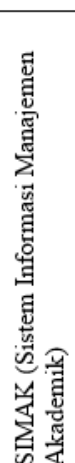 & 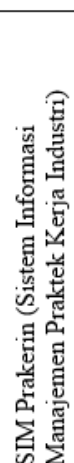 & 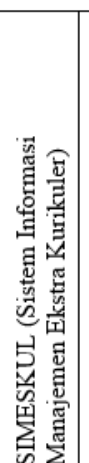 & 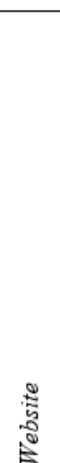 & 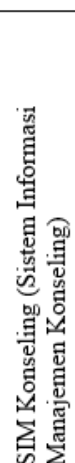 & 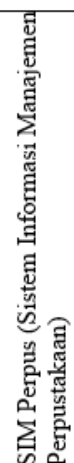 & 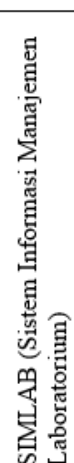 & 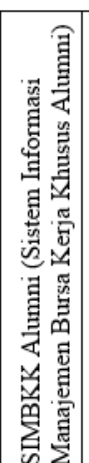 & 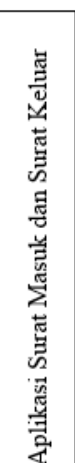 & 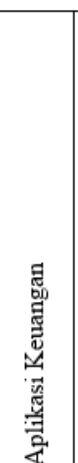 & 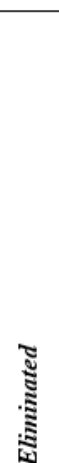 \\
\hline $\begin{array}{l}\text { Aplikasi Dapodik } \\
\text { (Data Pokok Pendidik) }\end{array}$ & RT & & & & & & & & & & & & \\
\hline Website & & & & & & $\mathrm{RP}$ & & & & & & & \\
\hline New & & ADD & ADD & ADD & ADD & & ADD & ADD & ADD & ADD & ADD & ADD & \\
\hline
\end{tabular}

Gambar 8. Matrix Analysis Gap Arsitektur Aplikasi

Gambar 8. merupakan hasil analisis gap dari aplikasi saat ini dan aplikasi yang diusulkan. Aplikasi Dapodik diberi keterangan RT (Retain), yang artinya aplikasi tersebut akan tetap dipertahankan atau tetap dan tidak mengalami perubahan atau pengembangan apapun. Website diberi keterangan RP (Replace), yang artinya aplikasi tersebut akan tetap digunakan namun akan dikembangkan agar dapat menunjang semua aktivitas.Sedangkan aplikasi yang lainnya diberi keterangan $A D D$, yang artinya aplikasi-aplikasi tersebut merupakan aplikasi baru yang akan ditambahkan dalam rancangan aplikasi yang diusulkan.

Menurut Gambar 8. yang merupakan Matrix dari analisis kesenjangan (gap) arsitektur aplikasi yang sedang berjalan saat ini dan aplikasi usulan, berikut dibuatlah sebuah pemetaan kategori dan konstribusinya dalam mencapai tujuan bisnis organisasi. Pemetaan tersebut menggunakan analisis portofolio aplikasi McFarlan Strategic Grid yang tertera pada Tabel 5 [12]. 
Tabel 5. Pemetaan Portofolio Aplikasi

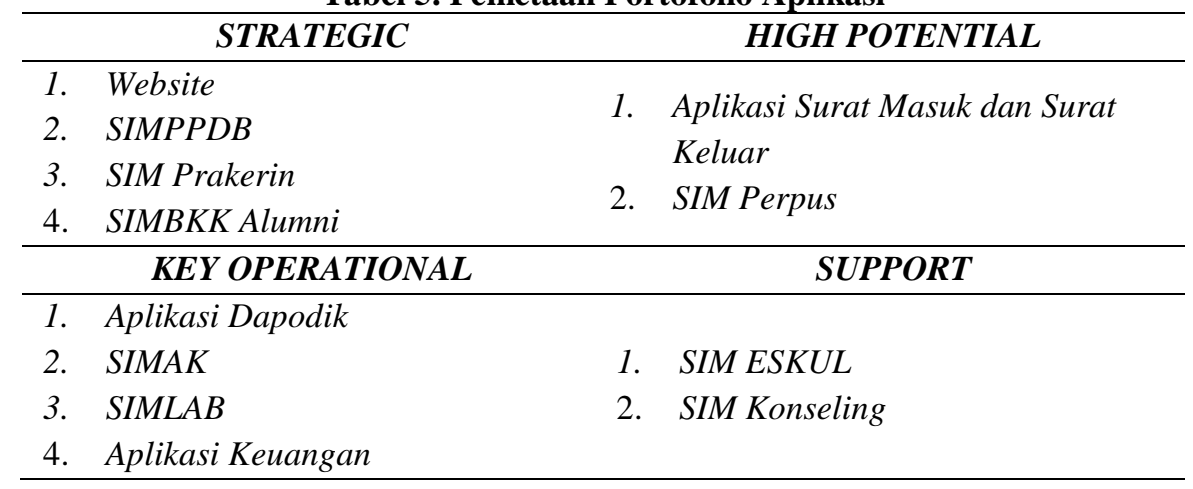

Penyusunan roadmap bertujuan untuk melakukan rencana proses peralihan dari sistem saat ini ke sistem baru. Penyusunan roadmap didasarkan pada pemetaan portofolio aplikasi, arsitektur TI usulan, dan manajemen SI/TI. Implementasi dibuat dalam waktu satu periode sama dengan satu tahun implementasi arsitektur SI/TI.

Implementasi aplikasi, disusun berdasarkan kategori yang paling utama dalam pemetaan menggunakan McFarlan Strategic Grid. Aplikasi dengan kategori key operational diimplementasikan pada periode ke-1, aplikasi dengan kategori strategic diimplementasikan pada periode ke-2, aplikasi dengan kategori high potential dan support diimplementasikan pada periode ke-3. Implementasi aplikasi website pada Gambar 8. merupakan aplikasi yang sedang berjalan saat ini dan akan mengalami pengembangan terhadap konten aplikasi. Tujuan dari diimplementasikannya pada periode ke-1 karena website dapat memberikan keunggulan bersaing dalam dunia kesehatan dan dapat mendukung kesuksesan SMK Kesehatan Hidayah Medika Tasikmalaya. Website menyediakan konten yang berisi informasi mengenai artikel-artikel kesehatan dibidang farmasi, keperawatan, serta analisis kesehatan lainnya. Hal tersebut dapat menarik minat masyarakat umum dan memberikan kesuksesan sebagai sekolah yang unggul dalam menjaring peserta didik baru dengan sebanyak-banyaknya.

Implementasi terhadap pengadaan hardware, pengembangan teknologi, dan perbaikan infrastruktur jaringan dilakukan selama kegiatan pengembangan aplikasi-aplikasi agar dapat disesuaikan dengan kebutuhan. Sedangkan pelatihan terhadap arsitektur SI/TI kepada para pegawai dilakukan setiap periode setelah arsitektur SI dan arsitektur TI berhasil diimplementasikan. Berikut ini roadmap implementasi arsitektur SI/TI yang tertera pada Tabel 6.

Tabel 6. Roadmap implementasi arsitektur dan Manajemen SI/TI

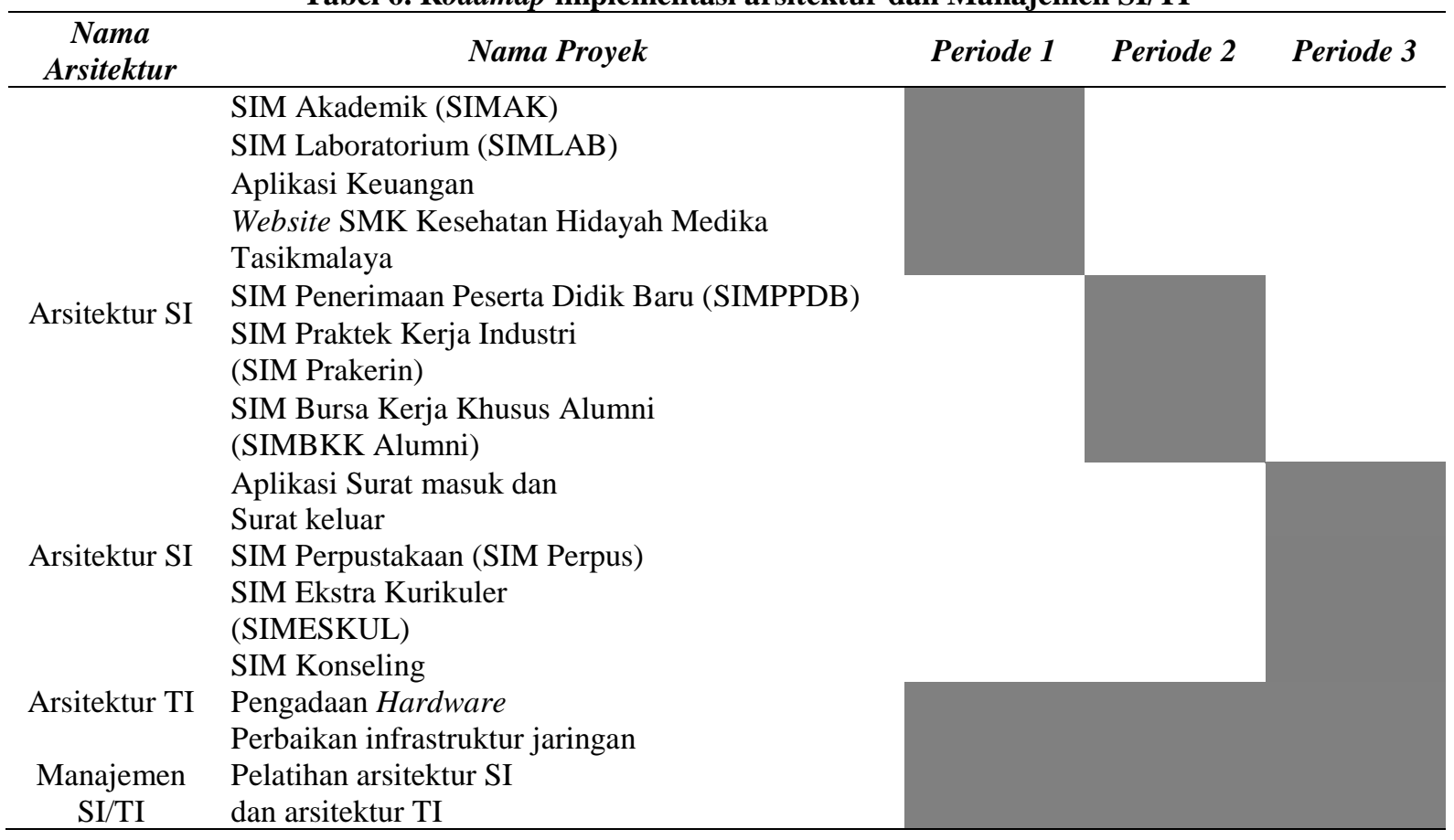




\section{KESIMPULAN}

Berdasarkan hasil dari penelitian yang telah dilakukan, maka dapat diambil kesimpulan yaitu perencanaan strategi SI/TI pada SMK Kesehatan Hidayah Medika Tasikmalaya menggunakan prinsip arsitektur enterprise menggunakan framework TOGAF versi 9.1 dengan ADM sebagai metode pengembangan arsitekturnya. Hasil dari perencanaan tersebut adalah blueprint untuk mendukung proses bisnis di SMK Kesehatan Hidayah Medika Tasikmalaya. Blueprint yang dihasilkan adalah 18 pemodelan Business Process Model and Notation (BPMN) untuk arsitektur bisnis, 11 pemodelan Use Case Diagram untuk arsitektur aplikasi, 11 pemodelan Class Diagram untuk arsitektur data, dan arsitektur teknologi yang menghasilkan infrastruktur jaringan usulan menggunakan communication enginering diagram, platform teknologi menggunakan platform decomposition diagram serta katalog teknologi menggunakan technology portfolio catalog.

Matrix gap analysis merupakan matrik hasil analisa dari kesenjangan (gap) arsitektur yang dilakukan. Analisa kesenjangan arsitektur yang dilakukan adalah arsitektur bisnis, aplikasi, data, dan teknologi dari sistem yang sedang berjalan dengan arsitektur SI/TI yang diusulkan.

Roadmap implementasi dari perencanaan arsitektur SI/TI dibagi kedalam tiga arsitektur yaitu arsitektur SI, arsitektur TI, dan manajemen arsitektur SI/TI. Implementasi dibuat dalam waktu satu periode sama dengan satu tahun implementasi arsitektur SI/TI yang disesuaikan dengan kebutuhan implementasi SMK Kesehatan Hidayah Medika Tasikmalaya.

\section{DAFTAR PUSTAKA}

[1] Rusniati and H. Ahsanul, "PERENCANAAN STRATEGIS DALAM PERSPEKTIF ORGANISASI," Jurnal INTEKNA, vol. 14, no. 2, pp. 102-209, 2014.

[2] K. Hendrik, "PEMODELAN ARSITEKTUR ENTERPRISE MENGGUNAKAN TOGAF ADM UNTUK MENDUKUNG SISTEM INFORMASI PROSES AKADEMIK PADA UNIVERSITAS MUHAMMADIYAH PONOROGO," Multitek Indonesia, vol. 8, no. 1, pp. 16-35, 2014.

[3] G. The Open, TOGAF Version 9.1, San Fransisco: The Open Group, 2011.

[4] B. S. Erwin, "PEMILIHAN EA FRAMEWORK," Seminar Nasional Aplikasi Teknologi Informasi 2009 (SNATI 2009), pp. B-114-B-199, 2009.

[5] N. S. Hasbu, "Perancangan Model Arsitektur Sistem Informasi Di Perguruan Tinggi Menggunakan Togaf Architecture Development Methode (Adm) (Studi Kasus: Universitas Suryakancana)," Media Jurnal Informatika, vol. 7, no. 2, pp. 9-27, 2015.

[6] Y. Roni and S. Kridanto, "PERANCANGAN MODEL ENTERPRISE ARCHITECTURE DENGAN TOGAF ARCHITECTURE DEVELOPMENT METHOD," Seminar Nasional Aplikasi Teknologi Informasi 2009 (SNATI 2009), pp. E-25-E-31, 2009.

[7] W. Tantri, F. R. Sandi and A. M. Amin, "ANALISIS ARSITEKTUR TEKNOLOGI INFORMASI PADA SMK NEGERI 1 MAJALENGKA MENGGUNAKAN FRAMEWORK TOGAF," Computatio: Journal of Computer Science and Information Systems, vol. 1, No. 1, pp. 66-80, 2017.

[8] R. Nela, Fitroh and F. F. Asep, "PERENCANAAN ARSITEKTUR ENTERPRISE MENGGUNAKAN TOGAF ADM VERSI 9 (Studi Kasus: Bimbel Salemba Group)," Studia Informatika: Jurnal Sistem Informasi, vol. 10, no. 1, pp. 11-20, 2017.

[9] S. Deris, "PERANCANGAN ARSITEKTUR ENTERPRISE SISTEM INFORMASI SEKOLAH DENGAN MENGGUNAKAN TOGAF ADM (Studi Kasus : SMK Informatika Sumedang)," Jurnal Ilmu-ilmu Informatika dan Manajemen STMIK Sumedang, vol. 10, no. 2, pp. 11-20, 2016.

[10] S. Kridanto, Pengembangan Rencana Induk Sistem Informasi, Bandung: Informatika, 2009.

[11] M. Porter, Competitive Advantage: Creating and Sustaining Superior Performance, New York: The Free Press, 1985.

[12] W. John and P. John, Strategic Planning for Information Systems Third Edition, England: John Willey \& Sons LTD, 2002. 